\title{
Emerging Trends in International Business and Trade: Need for a Paradigm Shift for Pakistani Trade Bodies
}

\author{
Abdul Rahman Zaki ${ }^{1}$ \\ ${ }^{1}$ Karachi University Business School, University of Karachi, Karachi, Pakistan \\ Correspondence: Abdul Rahman Zaki, Chairman, Karachi University Business School, University of Karachi, \\ Karachi, Pakistan. E-mail: abdulrahman.zaki@hotmail.com
}

Received: May 23, 2013

Accepted: June 18, 2013

Online Published: January 10, 2014

doi:10.5430/ijfr.v5n1p119

URL: http://dx.doi.org/10.5430/ijfr.v5n1p119

\begin{abstract}
The article aims to highlight the role of trade bodies and associations in contributing to economic growth of Pakistan. The economy of Pakistan has shown a downward trend for last couple of decades. However, according to an analysis by the global financial institutions, Pakistan is a promising economy, one of 22 that might lead the economic growth in the $21^{\text {st }}$ century. Moreover, the economy has seen a shift from being dependent on the agriculture to the industrial. Globalization of the worked trade has further necessitated a change in the role of trade bodies of the country. The private sector and trade bodies of Pakistan must not ignore their responsibility in this regard, because they are the ultimate beneficiaries of the economic growth. This article presents a literature review on the given issue and argues that now trade bodies and trade associations must play the role of economic catalysts by contributing to employment generation, participating in national exchequer and more importantly, by expanding their role in social, political, cultural and ideological development through research.
\end{abstract}

Keywords: trade bodies, economy, industry, globalization

\section{Introduction}

A couple of decades ago, Pakistan's economy was heavily dependent on agriculture, but over the years it has developed its manufacturing and service side. Still agricultural products account for more than one-fifth of output and two-fifths of employment in the country. Now Pakistan is world's $27^{\text {th }}$ largest economy in terms of purchasing power parity, yet the whole picture of the country's economy isn't very pretty.

Foreign exchange reserves are depleting in spite of overseas worker remittances and the trade gap caused by growing imports may further affect the GDP negatively. According to the UN Human Development Report, over the past few years, low growth and high inflation, preceded by an increase in food prices, have raised the level of poverty in the country bringing it to $50 \%$ of the population in 2011 . Inflation has seen a rise from $7.7 \%$ in 2007 to almost $12 \%$ for 2011 that aggravated the situation until it fell to $10 \%$ in 2012 . The continuous political and economic volatility has caused the Pakistani rupee to devalue more than 40\% since 2007. Although the economy has gained some stability since the 2008 crisis, it has not recovered from the meltdown. Foreign investment is at its lowest ebb because investors have concerns about governance, energy and security. This has in turn given rise to a slowing down of the economic activity also with regard to international business. Input coming from overseas workers is a positive side of the economy yet the current account saw a further deficit in fiscal year 2012, stimulated by higher prices for imported oil and lower prices for exported cotton. The overall growth on average figured at about $3 \%$ per year from 2008 to 2012.

Economists believe that Pakistan must address long standing issues related to government revenues and energy production in order to provide an incentive for economic growth. However, one area where financial institutions and trade organizations can play a significant role remains under-discussed. The role of trade associations is important in that they work to promote best practice in the industry, help companies become more competitive not only nationally but also internationally and develop and deliver effective public policy. These associations and organizations occupy a central position in the industry and are seen as the voice of the industry. In today's highly interconnected and globalized world, we must play our role in improving and expanding the connections with the rest of the world and our trade bodies must step forward in this direction. We are well past the time when the world was polarized into economic blocs and countries identified themselves with one or the other bloc. In our global village, we are now 
economies and this shift has cleared the front for the trade bodies to play a role in the development of their economy. We are now faced with new challenges- the globalization and free-trade zones- and this transition calls for a paradigm shift in the way trade bodies have been working.

The purpose of this article is to voice our concern regarding the limited role of trade bodies in Pakistan. First of all, the trade bodies must be able to represent all their members at every level and therefore give government and other authorities with the peace of mind that what is good for the sector is being taken care of. This understanding among the members causes the membership base to grow which in turn strengthens the authority of the trade association. Strong national trade bodies are an extremely powerful asset for members and the government since they represent the industry of the country at international forums. Secondly, they must realize that the private businesses they represent are the source of revenue and employment for the country. So they have a huge role to play in mobilizing the industry's potential to its fullest since by way of the growth of the industry they assist in the growth of the country's economy. Thirdly, trade associations ascertain the effects of policy measures on their sector and act as an agent to ensure that Government action achieves its desired purpose. Fourthly, Trade Associations can also work with other organizations in and out of the country with an interest to create some common ground for the mutual benefit of the industries. They should be able to work in close connection with Government to sponsor the professional networks, forums and alliances which can provide a focus for collaborative work with Government bodies on policy and delivery.

In the following discussion, I argue that now trade bodies and trade associations must play the role of economic catalysts by contributing to employment generation, participating in national exchequer and more importantly, by expanding their role in social, political, cultural and ideological development through research.

\section{The Traditional Role of Trade Bodies}

A trade association is formed when several companies within a specific industry work together for common interests. These organizations urge businesses to maintain and in turn raise standards of service and manufacturing and may also advantage consumers by addressing emerging problems through research and social service. Formally, Coleman and Jacek (1983) define industry associations as "Organizations created to represent business interests within specific domains, mobilizing firms within their domain so that collective action can be taken on common problems."

In a trade association, manufacturers, companies, or industries with similar products come together as a professional group whereby they respond to issues with consumers and provide product information through publications and other forms of publicity. They also create competitions among companies and promote fair trade practices. Nordqvist, Picard and Pesemaa (2010) believe that trade associations bond different industries and companies together so they would work together with focus on some common benefits and also provide a platform for sharing and publicizing on products.

Some time ago industry associations used to be seen as pressure groups that would be a party in labor and public policy discussions, but this view of trade associations started to change in the 1970s and 1980s (Coleman \& Jacek, 1983). With the passage of time their role has transformed into the ones working for a change. Industry associations are basically voluntary organizations and this means that their survival depends on the continuity of the existence of their members. This voluntary nature of these organizations exposes them to a continuing pressure to make their actions towards their present and potential members legitimate. According to Meyer (1994), there are mainly two types of organization: self-purposive organizations and organizations that function as regulatory others, and industry associations belong to the second category. They are organizations founded by other organizations to fulfill their collective purposes.

Recent technological developments have turned the world into a global village and it has also affected the way trade association would work. Now trade associations build cooperation, foster information sharing, offer training and provide a wide range of services designed to help members improve business performance. They influence industry norms and practices, standardize business practices and demand best practices. They also respond to threats to the industry and create opportunities for business. Because of their nature as voluntary organizations trade associations are not self-interested. Their focus is the benefit of member firms. Knowledge building, knowledge deployment, and standard setting are some common ways in which industry associations help firms (Damsgaard \& Lyytinen, 2001). Additionally, they engage in self regulation, develop codes of practice (Gunningham \& Rees, 1997; Clark, 1999; Haufler, 2001), and uphold favorable trade policies (Procassini, 1995; Sell, 1995). Industry associations monitor industry trends and trade development to achieve common benefits. They sponsor research and training activities, and engage in advocacy and outreach activities (Ernstthal and Bob, 1997; Cox, 2007). 
This discussion brings us to a pertinent question in the current scenario of Pakistani industry associations or trade associations, and that is: Should the role of Pakistani trade associations change as the world turned into a global village? If yes, in what ways can Pakistani trade associations help improve the economic situation of the country? In the following sections of the article I will try to answer this question. For this, I first present a brief overview of the demands of globalization and then outline my view on the issue. I argue that in the current economic scenario all over the world where countries have been quietly replaced by economies, the role of Pakistani trade bodies has become more important. We ourselves are a transitional economy and we need to make a paradigm shift to ready ourselves for the challenges of globalization and free trade regions.

\section{Demands of Globalization}

The term globalization has only recently become common. It is defined as the process of international integration arising from the interchange of world views, products, ideas, and other aspects of culture (Al-Rodhan and Stoudann, 2006). Globalization literally means "growth on a global or international scale". The Sociologist Martin Albrow defines globalization as "all those processes by which the peoples of the world are incorporated into a single world society" (1990, p.4). As far as economics and political economy is concerned, there is no specific and inclusive definition of the phenomenon of globalization, but there are many opinions. By and large, advancements in transportation and telecommunications infrastructure and the development of the Internet as the most important source of communication and knowledge are major elements that provided the thrust for globalization. These factors are also seen as a cause to the interdependence of economic and cultural activities.

One important change that has resulted from the growing globalization is the way countries now seek cooperation with other countries of the world. Owing to the fast developing means of communication, countries are looking for economic constancy by way of diplomatic relationships. A lot of countries have adopted or are on the way of adopting strategies and implement policies to actively engage in international environments as they affect the economy and politics of small countries. However, for a country like Pakistan, whose economy mainly depends on agriculture, it is very important also to understand how this trend in economy has developed out of the phenomenon of globalization for this might as well help her expand the economic prospects for its future.

However, globalization does not provide workable solutions for social problems like poverty, unemployment, illiteracy, underdevelopment, and cultural conflicts etc. A review of the recent history of nations reveals that these issues have been the definitive causes of the human insecurity and wars. Other means of reformulating the world's economic policies and political trends have been the large multinational corporations and cross border investment. The power and role of multinational corporations in building of the structure of national economic activities and development is not unknown to us. The power of multinational corporations to change the global political trends and economic policies is very visible in examples of East India Company, Standard Fruits in Honduras and Chinese gigantic business corporations in present era.

The development of an economy in today's world depends on the global policies and relations and it is important that we understand how these global polices take shape, who has stakes in them and who will benefit from them. Looking back at the history of nations we see that for winning wars like WW II, powerful governments and donor agencies as well as multinational corporations and analysts and researchers from different eras and regimes have seen these powerful elite groups of the businessmen as the governing and driving forces. Meher (2008) asserts that "Global assets and funds managers, scholars, NGOs, lobbyists, manipulators and even terrorist groups provide powerful influences in driving global policies and governing of the nations, while new technologies, internet, travelling and tourism activities, educational institutions, and electronic and print media are the tools of policy transformation". However, these are not the only forces that have shaped the global economic scene. Meher (2008) further points out that "Besides the UNO, multilateral agencies, elite business and economic groups and forums, and multinational companies, the other powerful but less prominent institutions in determining the global economic policies and political trends is the 'chamber of commerce"'. It seems important to mention here that chambers of commerce are not independent and isolated bodies, they integrate the power of different actors that operate at local national, regional and international levels.

George Ridgeway the author of 'Merchants of Peace: The History of the International Chamber of Commerce' (1956), talks about how the network of the UNO, International Chamber of commerce and the US national chambers of commerce works. He further points out that, "Through the efforts of the Chamber coalition the United Nations was born after World War II. And through the United Nations, the Chamber gained for the first time in history, a permanent vehicle for prescribing policy for governments". Discussing the power that the Chamber can exert he says that the priorities of the world of business are reorganized by the Chamber. According to him, most people, even the 
members of Chamber of Commerce, would be astounded by the extent of power this organisation exerts over international, national, state and local policies. Save for a few leaders at the top, most members do not come to know about how the Chamber actually works, that is the office of the Chamber which seems to be thinking locally, but actually works its magic globally. This magic however worked through two slogans that reflect the underlying policy of the Chamber and these slogans were: "World peace through world trade," and "More business in government and less government in business."

The National chamber of commerce represents the business sector of a country by way of its influence on and association with the local chambers and trade associations and creates links with the regional and international chambers of Commerce. More or less all the national chambers of commerce participate in the international economic policy dialogues. The national and regional chambers are aimed to participate in policymaking and economic governance in the globally integrated economies.

Apart from of the views by different analysts on the power and role of the chambers of commerce in governing the global policies, it is evident that "in the regime of free trade and globalisation, the role of the chambers has been largely extended. It does not only determine the economic and political trends and growth patterns, it affects also the advancement and governance of the human resources in a country" (Mehar, 2008).

In modern times the trade and business relationship between the trading countries in evident from the formation of Regional Economic Integration. A number of trade agreements and associations have been constituted to improve the economic conditions of the agreeing countries. World wide a number of goodies are created like EFTA, Custom Union, Common market Economic Union, European Union and others. A similar economic integration among Asian counties has also been created to facilitate trade and business. The idea is to help increase the trading opportunities for other countries and to boost up economic, business and political relationships. Globalization has created linkage between different countries of the world and helped to strengthen relationship by forming such economic integration through trade and business associations. Globalization and integration of world trade and association have created positive impact in creating world peace. These trade integration are on macro level but since Pakistan is still a developing nation the trade bodies at micro level are more important.

\section{The Changing Role of Trade Bodies}

The role and activities of the local chambers and trade associations usually seem to be concerned with issues of the local business community. They may want to be seen and heard in the policy-making processes on the basis of who they represent or the relevance of the expertise they offer in such dialogues. The interconnection of trade policies, foreign affairs, and cross border mobilization of capital signifies the role and scope of national and regional trade bodies. Trade associations that are represented in the national chamber of commerce can electrify their industries, bringing together severely competing companies to provide a single platform to support the sector's potential. The role of trade associations in Pakistan is even more fundamental because being a developing nation, we find it difficult o keep up with the fast pace of technological and economic advancement at the international level.

Steady routine of trade and economic activities may lead to a sustainable pace of economic development. The flow of investment, mobility of labour, forms of business financing and the strength of business institutions define the economic future of a people. This premise has been certified in all parts of the world and at all times. The only difference has been created by the magnitude of investment and trade activities that is required in today's global world.

Al-Rodhan and Stoudann (2006) argue that the competition, effects of one country's economic policies on others, increasing role of private sector in the national economies and a larger size of required investment have led way in the days of powerful trade organizations and chambers of commerce that are truly considered as engines of economic growth and the powerful catalysts for national development.

We are past the age of cold war when the terms like third world, communism, and nationalisation were adopted in one part of the world while the same things were taboos in another. Now, we breathe in the world that sees transitional economies that are preparing themselves for challenges of globalization and free trade. Now, the greater part of the responsibility of economic development lies with the private sector- a concept that is now called corporate social responsibility. In addition to this concept there are the notions of democratic approach to business and finance, corporate culture, fair trade, good governance and economic freedom and participation that need to be practiced in their true spirit.

Today, the issues in trade and investment are closely connected to the social ills of unemployment and poverty, and the lack of good governance seen in deteriorating infrastructure and high crime rate in a country. That is why issues 
concerning businesses couldn't be viewed or studied in isolation; they are integrated with the socio-political dimensions of an economy. In these circumstances, trade bodies will have to play important and non-traditional role and history has proven that they can be catalysts of economic development.

The ways trade associations can work toward the common goal of economic boost are policy advocacy, image building of the country's institutions and products in the international world, activation of think tanks working for technological advancement, co-ordination with the public serving organizations for better social service and bondage with the academia for research and policy studies. I outline below the ways the role of the national trade associations should be charted:

a. The fact of the matter is that if our trade associations begin with research first to find out what and where they need to mobilize the industry of our country it will be a great start. Multi-dimensional enhancement in the research activities will be the first step toward understanding the socio-economic needs of the country that will help us redraft our objectives for the future.

b. Not only that we mobilize our national chamber of commerce and industry and apply the growth models led by private sector but also to achieve the targets of economic co-operation with the regional chambers - including Islamic Chamber of Commerce and Industry, ECO Chamber of Commerce and Industry, SAARC Chamber of Commerce and Industry. This cooperation with the regional chambers of commerce and industry will play an influential role.

c. To achieve their long-term goals for economic growth and stability, trade bodies need to strategize politically and invest in the advocacy of public policies. One aspect of the working of the national chamber of commerce and industry in Pakistan that delimits the power of the chamber is it being regulated by the ministry of commerce. It restricts the role of the chamber to serve as a catalyst for national and regional economic development. The chamber and other trade bodies need to use the strategies of lobbying to wean themselves of this regulatory system to be able to play any significant role.

d. Another important area where the chamber can definitely play an important role is in terms of communication and co-ordination between national and regional associations. This can lead to the development of technological infrastructure that is key to good communication.

e. The rate of unemployment in a country gives us an insight into the future of the economy as well. A high rate of unemployment shows low economic growth. Raza (2012) points out that new business ventures are the main source of job creation at national level. For new and small indigenous business it is imperative that government provide basic infrastructure. In last five year energy crises has become a major problem for the government. This has also negatively affected the Doing Business Score of Pakistan. This has not only increased the cost of production but has made hiring new employees very difficult. Floods in recent years and our involvement in the war on terror have aggravated the problem of unemployment. Then there is this mushroom growth of private educational institutes that fail to produce skilled individuals. Every year universities and colleges in Pakistan produce thousands of graduates without ensuring their demand in local market, and not forecasting how such a huge human resource will absorbed in the industry. Trade associations can help improve the employment rate of the country in three ways: by supporting entrepreneurs, by providing sponsorship to educational institutions for research and higher studies and by lobbying for the development of the country's infrastructure.

\section{Conclusion}

Summing up the discussion above, it is high time we reset the standards, measures and objectives of industrial and trade development. Trade association can definitely play an important role in this regard. Today, the private sector and trade bodies cannot ignore their responsibility, because they are ultimate beneficiaries of the economic growth. There are 32 local chambers of commerce and 80 recognized trade associations in Pakistan that are members of the Federation of Pakistan Chamber of Commerce and Industries (FPCCI).

According to a report by Khan (2012), Pakistan has been chosen to be one of the 22 nations of the world to lead the economic development in the $21^{\text {st }}$ century. These countries currently account for $75 \%$ of global GDP and $70 \%$ of its population. It is pertinent to note that these 22 nations account for a mere $10 \%$ of the countries in the World Bank's global database. In spite of all the economic indicators that show a downward trend, the selection of Pakistan in 22 countries to lead the economic growth is a sign that a lot can be hoped from our economy. At this point in time, trade associations can play a very significant role. 


\section{References}

Albrow, M. (1990). Introduction. In Martin Albrow and Elizabeth King (Eds.), Globalization, Knowledge and Society: Readings from International Sociology (pp. 1-12). London: Sage.

Al-Rodhan, Nayef R.F., \& Stoudmann, G. (2006). Definitions of Globalization: A Comprehensive overview and a proposed definition. Geneva Centre for Security Policy, Geneva. Retrieved from http://www.sustainablehistory.com/articles/definitions-of-globalization.pdf

Clarke, Roger. (1999). Internet privacy concerns confirm the case for intervention. Communications of the ACM, 42(2), 60-67. http://dx.doi.org/10.1145/293411.293475

Coleman, William D., \& Jacek, Henry J. (1983). The roles and activities of business interest associations in Canada. Canadian Journal of Political Science, 16(2), 257-280. http://dx.doi.org/10.1017/S0008423900023246

Cox, John B., editor. (2007). Professional Practices in Association Management: The Essential Resource for Effective Management of Nonprofit Organizations (2nd ed.). Washington, D.C.: American Society of Association Executives.

Damsgaard J., \& Lyytinen K. (2001). The Role of Intermediating Institutions in the Diffusion of Electronic Data Interchange (EDI): How Industry Associations Intervened in Denmark, Finland, and Hong Kong. The Information Society, 17(3), 195-210. http://dx.doi.org/10.1080/01972240152493056

Ernstthal, Henry, \& Jones, Bob (1997). Principles of Association Management (4th ed.). Washington, D.C.: American Society of Association Executives.

Gunningham, N., \& Rees, J. (1997). Industry Self-Regulation, An Institutional Perspective. Law and Policy, 19, 4. http://dx.doi.org/10.1111/1467-9930.t01-1-00033

Haufler, Virginia. (2001). A Public Role for the Private Sector: Industry Self-Regulation in the Global Economy. Washington, D.C.: Carnegie Endowment for International Peace.

Khan, S., \& Amanullah. (2012, August 6). Pakistan among chosen 22 to lead economic growth. Express Tribune. Karachi.

Mattias Nordqvist, Robert G. Picard, \& Ossi Pesämaa. (2010). Industry Associations as Change Agents: The Institutional Roles of Newspaper Associations. Journal of Media Business Studies, 7(3), 51-69.

Meher, A. (2008). Role of Trade Associations in Economic Development. MPRA_Paper. Retrieved from http://mpra.ub.uni-muenchen.de/18590/

Procassini, Andrew A. (1995). Competitors in Alliance: Industry Associations, Global Rivalries and Business-Government Relations. Quorum Books.

Raza, M. (2012, February). Leading Indicator And Pakistan Economy in 2012. Diplomatic Circle. Retrieved from http://www.diplomaticcircle.com/Feb12_Articles/pakistan_economy.php

Ridgeway, G. (1956). Merchant of peace: The History of International Chambers of Commerce. New York: Columbia University Press.

Sell, Susan K. (1995). The Origins of a Trade-Based Approach to Intellectual Property Protection: The Role of

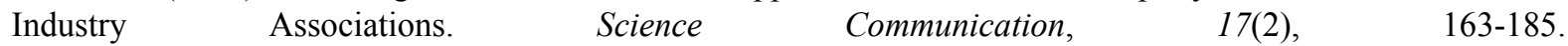
http://dx.doi.org/10.1177/1075547095017002004 